\title{
Prospek Pusat Informasi dan Perpustakaan dalam Perkembangan Information And Communication Technology (ICT) : Tinjauan Komprehensif Nilai Filosofi Ilmu Informasi dan Perpustakaan
}

\author{
Rahmat Iswanto ${ }^{1}$, Sulistyowati ${ }^{2}$ \\ Sekolah Tinggi Agama Islam Negeri (STAIN) Curup \\ 1e-mail: rahmatiswanto.database@gmail.com \\ 2email: sulisw891@gmail.com
}

\begin{abstract}
This article is intended to see the future existence of the institution of information center and library as an institution that will continue to exist even if the information could be found by the community easily through the development of information and communication technology. In the present, people can access information through any approach in the world's information network known as the internet. Moreover, if in the future the ability of people to choose the type of information needed better. Therefore it becomes a matter as how the prospect of information center and library in the development of Information and Communication Technology (ICT). By exploring the Information Science and Library as a fundamental branch of science, both seen from ontology, epistemology, and axiology is expected to know the basics of the prospects of information centers and libraries. The things that the information center and library should do will be seen through this assessment so that it will provide very useful inputs.
\end{abstract}

Key Words: Information Center; Library; Information Technology; Communication Technology

\section{Abstrak}

Tulisan tentang prospek pusat informasi dan perpustakaan ini dimaksudkan untuk melihat masa depan eksistensi lembaga tersebut sebagai lembaga yang tetap akan eksis meskipun informasi yang dijumpai oleh masyarakat dengan mudah dapat dicari melalui perkembangan teknologi informasi dan komunikasi. Pada masa sekarang, dengan perkembangan teknologi yang luar biasa, masyarakat dapat mengakses informasi melalui pendekatan apa pun di jaringan informasi dunia yang dikenal dengan internet. Terlebih lagi jika pada masa yang akan datang kemampuan masyarakat untuk memilih jenis informasi yang dibutuhkan menjadi cukup baik. Oleh karena itu menjadi suatu permasalahan bagaimana prospek lembaga pusat informasi dan 
perpustakaan dalam perkembangan Information And Communication Technology (ICT). Dengan mengupas Ilmu Informasi dan Perpustakaan sebagai cabang ilmu yang mendasar, baik dilihat dari ontologi, epistemologi, maupun aksiologinya diharapkan dapat mengetahui secara mendasar pula prospek pusat informasi dan perpustakaan. Hal-hal yang harus dilakukan oleh lembaga pusat informasi dan perpustakaan akan terlihat melalui pengkajian ini sehingga akan memberikan masukan-masukan yang sangat bermanfaat.

Kata Kunci : Pusat Informasi; Perpustakaan; Teknologi Informasi; Teknologi Komunikasi

\section{A. PENDAHULUAN}

Perpustakaan memiliki fungsi penting dalam perkembangan ilmu, hal ini karena kebutuhan sumber daya informasi bagi masyarakat dapat dilakukan dengan maksimal melalui lembaga seperti perpustakaan dan pusat informasi. Pada lingkungan universitas dan perguruan tinggi, perpustakaan disebutkan sebagai jantungnya perguruan tinggi karena melihat pentingnya lembaga tersebut.

Pada keadaan yang lain, perkembangan teknologi memberikan kesempatan dan kemudahan masyarakat untuk mendapatkan informasi yang mereka butuhkan. Kemajuan mudahnya masyarakat mengakses informasi yang mereka butuhkan menimbulkan pertanyaan dan dugaan bahwa fungsi perpustakaan sebagai penyedia sumber daya informasi akan berkurang bahkan akan diabaikan.

Perpustakaan dan pusat informasi menjadi suatu lembaga yang didasari oleh sebuah dasar keilmuan yang kuat sehingga lembaga ini adalah bentuk implementasi atau terapan bagi dasar ilmu tersebut. Bagaimana dasar keilmuan perpustakaan dan pusat informasi ini akan dijabarkan dan dibahas sehingga keberadaan kelembagaan ini akan diletakkan dengan baik dalam memberikan fungsinya ditengah perkembangan teknologi.

\section{B. HASIL DAN PEMBAHASAN}

\section{Ontologi Ilmu Informasi dan Perpustakaan.}

Berdasarkan Suriasumantri bahwa ontologi adalah sesuatu yang menyangkut hakikat apa yang akan dikaji (Suriasumantri, 1993). Dalam ontologi dibedakan antara obyek material dan obyek formal. Obyek material adalah eksisten konkret yang seutuhnya merupakan sasaran intensionalitas subyek, sedangkan obyek formal adalah ciri atau aspek khusus (bentuk) yang ditonjolkan untuk menyimak keutuhan itu. Sebagai contoh manusia adalah 
obyek material sedangkan ilmu kedokteran, ilmu psikologi, ilmu seni, dan lain-lain yang merupakan kajian berdasarkan konteks dari obyek material manusia itu menjadi obyek formal.

\section{Ilmu Informasi}

Ontologi Ilmu Informasi dapat dilihat dari tiga sudut yaitu arti sempit, arti lebih luas, dan arti paling luas (Dick, 2002). Arti sempit informasi ditafsirkan dalam arti sinyal atau berita yang tidak mencakup pengolahan kognitif. Arti lebih luas mencakup pengolahan dan pemahaman kognitif yang berasal dari interaksi antara dua struktur kognitif yaitu pikiran dan teks. Arti paling luas yaitu informasi tidak hanya bermakna berita yang diolah secara kognitif melainkan juga dikaitkan dalam konteks situasi, tugas, masalah yang dihadapi, dan lain-lain.

Saracevic mendefinisikan informasi dalam bentuk yang ketiga yang akan digunakan dalam ilmu informasi karena informasi digunakan dalam konteks temu balik informasi (Saracevic, 1999).

Berdasarkan kajian analisis co-cited authors akan menjadi lebih spesifik lagi, White dan McCain menyebutkan bahwa bidang khusus ilmu informasi adalah temu balik eksperimental; analisis sitiran; temu balik praktis; teori umum sistem perpustakaan termasuk otomasi perpustakaan; komunikasi ilmu pengetahuan (dalam arti luas); kajian dan teori pemakai; Online Public Access Catalogue (OPAC); ide yang berasal dari disiplin lain seperti ilmu kognitif, teori informasi, ilmu komputer; teori pengindeksan; teori sitiran; dan teori komunikasi (White \& McCain, 1998).

2. Ilmu Perpustakaan

Dalam Ilmu Perpustakaan, obyek materialnya adalah informasi terekam dengan tidak memandang media maupun formatnya. Sedangkan obyek formalnya berupa informasi terekam sebagai hasil cantuman grafis manusia yang berisi pengetahuan umat manusia (Sulistyo-Basuki, 2003).

\section{Kaitan Ilmu Informasi dan Ilmu Perpustakaan.}

Ilmu Informasi dan Perpustakaan merupakan satu kesatuan dengan karakter, obyek dan metode yang berbeda. Bagaikan dua sisi mata uang yang berlainan namun terdapat dalam satu kesatuan. Kesatuan tersebut merupakan ontologi Ilmu Informasi dan Perpustakaan.

Saracevic (1999) mencoba membuat garis pemisah antara ilmu informasi dengan kepustakawanan. Garis pemisah ini agak samar, dan lebih merupakan daftar hal-hal yang dikerjakan di masing-masing bidang. 
Hawkins menggunakan information science abstracts sebagai patokan untuk melihat tulisan-tulisan utama di bidang informasi dan perpustakaan. Untuk memastikan perbedaan antara keduanya, Hawkins merasa perlu memeriksa dan membandingkan klasifikasi subyek yang digunakan di dalam Library and Information Science abstracts (LISA) dengan yang digunakan di dalam Information Science Abstracts (Hawkins, 2001). Hasilnya adalah sebagai berikut:

\begin{tabular}{ll}
\hline \multicolumn{1}{c}{ Subyek Kepustakawanan } & \multicolumn{1}{c}{ Subyek Ilmu Informasi } \\
\hline Bahan langka (rare materials) & Aspek teknis dari teknologi informasi \\
Bahan non-cetak & Ilmu perilaku \\
Bahan pustaka dan perpustakaan & Industri informasi \\
Bangunan perpustakaan (library materials) & Intelegensi buatan, sistem pakar \\
Bentuk-bentuk mikro & Jenis literatur \\
Eksibisi pustaka & Logika fuzzy, dan pencarian fuzzy \\
Furnitur & Membaca (literacy) \\
Jasa peminjaman & Pangkalan data \\
Kearsipan & Penelitian dasar ilmu informasi \\
Kepustakawanan dunia & Pengolahan bahasa alamiah \\
Manajemen, pendanaan, keuangan & Profesional informasi \\
Mobil perpustakaan & Undang-undang dan regulasi \\
Museum & \\
Organisasi perpustakaan & \\
Pemindahan buku & \\
Pengguna & \\
Penggunaan perpustakaan dan penggunanya & \\
Promosi & \\
\hline Staf perpustakaan & \\
\hline
\end{tabular}

Nilai Ilmu Informasi dan Perpustakaan Dilihat dari Epistemologi dan Aksiologinya.

Kajian berdasarkan epistemologi adalah cara mendapatkan pengetahuan Ilmu Informasi dan Perpustakaan yang benar. Di sini meliputi metode ilmiah yang mempunyai ciri khas.

Putu Laxman Pendit (Pendit, 2003) menggambarkan perbandingan umum berbagai paradigma ilmu untuk membantu bagaimana Ilmu Informasi dan Perpustakaan dapat dilihat berdasarkan metode ilmiahnya. Perbandingan epistemologi pada beberapa paradigma tersebut dapat dilihat dalam table.

\begin{tabular}{llll}
\hline & Positivisme & Interpretivisme/Konstruktivisme \\
\hline Positivisme & $\begin{array}{l}\text { Pasca } \\
\text { Positivisme/Realisme } \\
\end{array}$ & & Teori Kritis \\
& Radikal & & \\
\hline Realitas bersifat & Peneliti tidak bisa & Peneliti selalu & Peneliti selalu \\
\hline
\end{tabular}




\begin{tabular}{|c|c|c|c|}
\hline $\begin{array}{l}\text { obyektif dan } \\
\text { peneliti harus } \\
\text { mengurangi } \\
\text { subyektifitas } \\
\text { sehingga menjadi } \\
\text { netral } \\
\text { Nilai dan etika, } \\
\text { moral harus } \\
\text { diletakkan di luar } \\
\text { penelitian, } \\
\text { peneliti adalah } \\
\text { disinterested } \\
\text { scientist }\end{array}$ & $\begin{array}{l}\text { sepenuhnya obyektif, } \\
\text { perlu ada kritik terus } \\
\text { menerus. } \\
\text { Nilai dan etika } \\
\text { dimasukkan dalam } \\
\text { penelitian, tetapi } \\
\text { peneliti adalah } \\
\text { mediator (tetap netral, } \\
\text { berada di tengah) }\end{array}$ & $\begin{array}{l}\text { harus berinteraksi } \\
\text { dengan manusia } \\
\text { lain untuk } \\
\text { membangun } \\
\text { realitas bersama. } \\
\text { Nilai dan etika } \\
\text { merupakan bagian } \\
\text { tak terpisahkan } \\
\text { dari penelitian, } \\
\text { peneliti adalah } \\
\text { partisipan aktif } \\
\text { yang merangkum } \\
\text { keragaman } \\
\text { subyektifitas } \\
\text { dalam penelitian }\end{array}$ & $\begin{array}{l}\text { memiliki nilai yang } \\
\text { menentukan apa yang } \\
\text { dilihatnya. } \\
\text { Nilai dan etika } \\
\text { merupakan pilihan } \\
\text { penelitian yang } \\
\text { disengaja, peneliti } \\
\text { adalah aktivis } \\
\text { ideologi. }\end{array}$ \\
\hline
\end{tabular}

Lebih lanjut Putu menjabarkan beberapa topik kajian Ilmu Informasi dan Perpustakaan berdasarkan paradigma-paradigma yang ada. Positivisme dalam Ilmu Informasi dan Perpustakaan dicontohkan dengan permasalahan bibliometrika dan prinsip sains; prinsip efisiensi institusi perpustakaan; klasifikasi dan ketertiban rasionalitas; eksperimen Cranfield; Brookes dan dunia tiga Popper; struktur kognitif dan keperilakuan. Sedangkan Interpretivisme dalam Ilmu Informasi dan Perpustakaan dicontohkan pada kritik terhadap definisi pengetahuan; aspek manusia; informasi dan hermenetika-eksistensialis; anti linguistik-positivis; peran sistem informasi dalam rekayasa sosial.

Kajian Ilmu Informasi dan Perpustakaan berdasarkan aksiologi adalah melihat kegunaan ilmu tersebut. Kegunaan ini yang akan membawa kita pada pembahasan eksistensi dan prospeknya dalam perkembangan Information Communication Technology (ICT).

\section{Perkembangan Information Communication Technology (ICT) dan Pengaruhnya dengan Pusat Informasi dan Perpustakaan}

Perkembangan ICT yang begitu pesat membawa perubahan di berbagai aspek kehidupan di masyarakat dan dunia. Baik aspek sosial, politik, budaya, pendidikan, termasuk ekonomi.

Pada sektor ekonomi, kini faktor produksi yang penting dan dominan telah beralih ke sumber daya informasi dan pengetahuan. Informasi tidak lagi sekedar pelengkap dalam kegiatan perekonomian saja. Informasi kini digunakan dan dimanfaatkan secara optimal dalam kegiatan perekonomian, sehingga memungkinkan diterapkannya cara-cara baru yang lebih efisien untuk produksi, distribusi dan konsumsi barang dan jasa, sehingga akhirnya 
akan meningkatkan produktivitas. Proses inilah yang membawa manusia ke dalam Masyarakat atau Ekonomi Informasi, atau disebut juga sebagai masyarakat pasca industri (wardiana, 2007)

Di era ekonomi informasi ini, informasi menjadi sangat berharga dan bernilai tinggi. Informasi dapat menjadi penentu keberhasilan perekonomian suatu bangsa, atau suatu perusahaan bisnis yang pada akhirnya berdampak pada kesejahteraan masyarakat. Dan ICT memegang peranan sangat penting di era ini.

Informasi dengan segala sifat dan karakternya yang unik, berbeda dengan sumber daya lainnya di sektor perekonomian, masih sulit untuk diukur. Bahkan ICT yang merupakan bagian tak terpisahkan dari ekonomi informasi juga masih belum bisa diukur secara memuaskan tingkat manfaat dari produktivitas dan pertumbuhan ICT di tataran ekonomi makro. Namun demikian, ada beberapa pendekatan dalam pengukuran ekonomi informasi, terkait dengan ICT yang dapat dijadikan acuan dalam mengukur ekonomi informasi.

Informasi yang kini menjadi begitu bernilai dan berharga, khususnya di sektor ekonomi, menjadi suatu tantangan tersendiri bagi lembaga pengelola informasi seperti perpustakaan. Perpustakaan sebagai pusat sumber daya informasi yang mengelola informasi harus terus mengikuti perkembangan yang terjadi di masyarakat, sehingga dapat menyesuaikan diri dan mampu memberikan jasa dan layanan yang bisa memenuhi kebutuhan informasi masyarakat penggunanya. Begitu juga pustakawan yang harus terus meningkatakan kompetensi dirinya, sehingga dapat menggunakan keahlian, kemampuan dan keterampilannya dalam mengelola informasi di era ekonomi informasi ini. Semua hal tersebut perlu dilakukan agar eksistensi perpustakaan dan pustakawan semakin dirasakan manfaat dan pentingnya.

Motor utama transformasi yang sedang melanda jagad raya dewasa ini adalah perkembangan pesat di bidang infrastruktur informasi yang ditunjang oleh kemajuan teknologi informasi dan komunikasi.

Bakir menjabarkan bahwa dalam tahap masyarakat industri, jalan raya (highway road) menjadi ciri pentingnya, karena jalan raya menunjang proses urbanisasi, produksi, dan distribusi massa yang terjadi. Dalam masyarakat informasi, ciri pentingnya adalah information highway (Iway), di mana jaringan komputer (internet) bisa menghubungkan siapa pun dengan yang lainnya dengan kecepatan yang tinggi (konektifitas). Dalam masyarakat seperti itu, orang akan tergantung pada jaringan informasi elektronik dan komunikasi yang kompleks dan yang mengalokasikan sumber dayanya 
sebagian besar untuk kegiatan informasi dan komunikasi. Bahkan informasi dan pengetahuan itu sendiri menjadi sumber daya dan faktor produksi baru yang penting. Dalam tahap perekonomian informasi yang demikian, sumber kapital, sumber alam tidaklah penting lagi. Kunci peranan dipegang oleh tenaga ahli (knowledge workers) yang memiliki dan menguasai teknologi. Korea, Taiwan, dan Singapura, tidak lah tergolong negara yang memiliki sumber daya alam yang kaya, bahkan dapat dikatakan kekayaan di bidang itu sangat minim. Kemajuan dan transformasi yang mereka alami, berkat pembangunan teknologi dan sumber daya manusianya (Bakir, 2007).

ICT menghasilkan manfaat akibat network effect dan inovasi model bisnis. ICT dipandang mampu meraih manfaat penciptaan nilai (value creation) akibat sinergi, kolaborasi, dalam jaringan ke arah customer, mitra kerja dan para pemasok. Sebagai contoh, satu keunggulan transaksi internet antar usaha meningkat karena perusahaan terkoneksi dengan jaringan - setiap investasi baru dalam suatu koneksi memberi keuntungan tidak hanya untuk investor, melainkan juga untuk partisipan lainnya (co-evolution). Dampak positif dari keterhubungan dalam jaringan, memperbaiki semua produktivitas dan pertumbuhan pendapatan agregat yang berpotensi menguntungkan semua partisipan pasar (Utoyo, 2007).

ICT dapat dimanfaatkan untuk mendekatkan perusahaan dengan pelanggan, di antaranya dengan memberikan layanan secara individu kepada mereka. Perusahaan dapat memperkenalkan produk, layanan baru yang ditawarkan serta berbagai solusi untuk memecahkan berbagai masalah yang dihadapi pelanggan, langsung ke tempat tiap-tiap pelanggan berada. Selain itu, pelanggan juga dapat membeikan keluhan, usulan, pertanyaan secara langsung kepada perusahaan, untuk memperbaiki kualitas produk dan layanan bagi pelanggan, serta menciptakan produk dan layanan baru sesuai dengan perubahan selera dan kebutuhan pelanggan yang bisa diakses dari setiap transaksi yang tercatat. Dell Computers, perusahaan yang memproduksi komputer dengan mengandalkan keterlibatan pelanggan dalam menentukan sendiri fitur dari komputer yang akan dibeli. Amazon.com juga mengandalkan keterlibatan pelanggan dengan konsep swalayan (pelanggan bisa memilih sendiri buku yang akan dibeli, dengan harga yang paling sesuai dengan kemampuan).

\section{Pengaruh ICT terhadap Pusat Informasi dan Perpustakaan}

Dampak dari perkembangan teknologi informasi dan komunikasi yang selanjutnya disingkat ICT (Information and Communication Technology) begitu terasa. Perkembangan ICT yang begitu pesat membawa 
perubahan di berbagai aspek kehidupan di masyarakat dan dunia. Baik aspek sosial, politik, budaya, pendidikan, termasuk ekonomi. Pada sektor ekonomi, kini faktor produksi yang penting dan dominan telah beralih ke sumber daya informasi dan pengetahuan.

Informasi kini digunakan dan dimanfaatkan secara optimal dalam kegiatan perekonomian, sehingga memungkinkan diterapkannya cara-cara baru yang lebih efisien untuk produksi, distribusi dan konsumsi barang dan jasa, sehingga akhirnya akan meningkatkan produktivitas. Proses inilah yang membawa manusia ke dalam Masyarakat atau Ekonomi Informasi, atau disebut juga sebagai masyarakat pasca industri.

Peranan teknologi informasi dan komunikasi juga dirasakan sangat besar untuk penyelenggaraan pendidikan jarak jauh. Renstra Depdiknas Tahun 2005-2009, menegaskan pemanfaatan ICT sebagai sarana pembelajaran jarak jauh; prioritas renstra adalah mengembangkan sistem pembelajaran jarak jauh (distance learning) di perguruan tinggi, pendidikan formal dan pendidikan non formal untuk mendukung perluasan dan pemerataan pendidikan.

Berdasarkan pertimbangan di atas ICT yang dibutuhkan adalah media cetak, radio, televisi, komputer dann jaringan internet (Warsita, 2007). Semua fasilitas tersebut harus ditempatkan pada suatu fungsi yang sama dalam menunjang pendidikan dan pengajaran dan untuk mengatasi masalah ini, perpustakaan adalah wadah yang sangat tepat sebagai pusat sumber informasi.

Sekarang, siapa yang menguasai informasi, merekalah yang akan menguasai dunia. Perubahan cepat di dunia bisnis mendorong perusahaan mengandalkan kekuatan informasi sebagai basis untuk berbisnis. Informasi yang didukung teknologi internet telah merevolusi wajah perekonomian dunia untuk berubah dari ekonomi lama (old economy) ke ekonomi baru (new economy). Dalam rangka itu, dibutuhkan pengelolaan informasi yang baik dan lebih terarah, dengan demikian dapat dimanfaatkan secara optimal. Peran inilah yang dapat diambil oleh perpustakaan atau unit informasi di suatu organisasi bisnis. Dan dibutuhkan pustakawan / profesional informasi dengan kompetensi yang tinggi untuk menjalankan pengelolaannya.

\section{Prospek Pusat Informasi dan Perpustakaan}

Kunci pemberdayaan perpustakaan di abad teknologi terletak pada kemampuannya mengidentifikasi, mengantisipasi, dan menanggapi dengan cepat perubahan kebutuhan pengguna. Fungsi penting perpustakaan, menurut 
Lancaster (1997) seperti yang dikutip Ratnawati, adalah mengelola sumbersumber informasi menjadi sesuatu yang bernilai bagi penggunanya. Sistem ini membimbing pengguna menuju sumber informasi yang kadang rumit dan kompleks melalui cara yang cepat dan mudah.

Ratnawati juga mengungkapkan bahwa, dengan adanya banjir informasi, perpustakaan dapat menciptakan jenjang akses berdasarkan kualitas ulasan materinya. Perpustakaan dapat menjadi :

- Access provider.

sumber informasi yang tinggi tingkat pemakaiannya dapat di download dan disimpan dan di update di dalam jaringan. untuk jenis informasi lainnya, dapat disediakan sesuai permintaan. ini dapat didahului dengan konsultasi melalui e-mail atau yang lainnya

- Switching centre

Untuk sumber informasi yang tidak dimiliki, perpustakaan dapat mengarahkan atau mengalihkan pengguna ke sumber informasi lain yang tepat

- Penyusun dan dan penyedia panduan, indeks, anotasi, dan alat bantu lain yang sesuai dengan kebutuhan dan minat penggunanya

$\circ$ filter

Peran perpustakaan / unit informasi di era ekonomi informasi adalah sebagai pelaksana knowledge and information management. Manfaat dari konsep manajemen pengetahuan adalah untuk meningkatkan fungsi dan kinerja perpustakaan. Manajemen pengetahuan dapat dijadikan sebagai pemicu agar pustakawan lebih inovatif dan kreatif dalam menyiasati cakupan muatan informasi dan pengetahuan yang dibutuhkan perusahaan / lembaga yang menaunginya, termasuk dalam bentuk elektronik. Masih banyak muatan pengetahuan eksplisit yang belum tersedia dalam bentuk elektronik yang sesungguhnya dibutuhkan oleh para pengguna perpustakaan. Pustakawan juga harus berupaya mengidentifikasi pengetahuan implisit dan mengembangkan sistem yang diperlukan untuk menanganinya. Walaupun hal yang disebutkan terakhir bukan pekerjaan yang mudah, tetapi prakarsa ke arah itu harus ditumbuhkan dan sedapat mungkin diimplementasikan (Hartono, 2007).

Seperti telah disebutkan di atas, Hartono juga menegaskan bahwa manajemen pengetahuan di lingkungan perpustakaan dapat dikembangkan dan diimplementasikan sebagai perluasan prakarsa perpustakaan elektronik. 
Bagi perpustakaan yang telah mengembangkan perpustakaan elektronik selama ini, yang diperlukan adalah mengintegrasikan konsep manajemen pengetahuan dalam hal pemerolehan, pengorganisasian, pemeliharaan, dan pendistribusian pengetahuan termasuk pengetahuan informal, tidak terstruktur, dan eksternal yang menyangkut lembaga induknya. Perpustakaan yang belum memiliki perpustakaan elektronik harus mulai mengembangkannya kalau masih tetap ingin dipandang sebagai penyedia informasi dan pengetahuan yang utama.

Untuk itu, berbagai perangkat pendukung yang diperlukan harus dipersiapkan termasuk organisasi dan kebijakan yang harus ditetapkan pada tingkat institusi induk perpustakaan. Di dalam organisasi perpustakaan harus terdapat satu bagian atau satu tim yang menangani pengorganisasian dan penyediaan pelayanan manajemen pengetahuan. Selain itu, perpustakaan harus aktif mengidentifikasi berbagai pengetahuan yang diciptakan di lingkungannya baik yang merupakan karya perorangan/kelompok maupun karya institusional.

Selain itu, perpustakaan / unit informasi dapat melakukan audit informasi (Information audit), yaitu suatu cara yang efektif untuk mengidentifikasi kebutuhan informasi organisasi, memetakan arus informasi dari dalam dan luar, mengembangkan komunikasi antara profesional informasi dengan para pekerja, pemasaran layanan informasi dan pengembangan profil perpustakaan dalam organisasi (Henczel, 2007). Dengan audit informasi, perpustakaan dapat mengevaluasi informasi yang dibutuhkan organisasi yang menaunginya., sehingga dapat memberikan produk-produk informasi yang lebih berkualitas.

Information repackaging dapat menjadi nilai tambah bagi perpustakaan dalam memberikan layanan informasinya bagi organisasi / perusahaan yang menaunginya. Istilah kemas ulang informasi berasal dari bahasa Inggris, yaitu 'Information Repackaging'. Dalam pengertian yang sederhana menurut John Agada (1995: 2) seperti yang dikutip Syamsudin (2007) kemas ulang informasi adalah sebuah unit layanan baru yang ada di perpustakaan atau pusat-pusat informasi yang memberikan layanan informasi untuk kebutuhan spesifik dari pemakai. Pengertian yang dikemukakan di atas, memberikan gambaran pada kita bahwa kemas ulang informasi merupakan sebuah unit layanan yang baru, layanan ini muncul atau disediakan terutama untuk menyahuti perkembangan dari melimpahnya informasi di era globalisasi informasi sekarang ini. Walaupun informasi yang tersedia di era ini melimpah ruah namun hal itu malah membuat kesulitan untuk mengakses informasi yang relevan, current dan komprehenship. 
Aspek yang kedua dari pengertian kemas ulang informasi yang dikemukakan John Agada tersebut adalah kegiatan layanan kemas ulang informasi yang diberikan harus benar-benar memberikan layanan kebutuhan yang spesifik untuk para pemakai perpustakaan atau pusat-pusat informasi.

Contoh dari kemas ulang informasi yang dapat dilakukan oleh perpustakaan bagi industri adalah (Hariyadi, 2007) :

- $\quad$ Brosur iklan dan promosi

- $\quad$ Analisa pasar dan trend pasar

- $\quad$ Analisa pesaing

- $\quad$ Analisa ekonomi

- $\quad$ Informasi mengenai paten-paten yang berkaitan, dan lain-lain.

Di masa kompetisi bisnis yang tinggi, setiap aktivitas di perusahaan harus dipastikan memberikan kontribusi pasti di dalam proses bisnis perusahaan tersebut. Hal ini menjadi tantangan bagi aktivitas non-core dalam proses bisnis seperti layanan informasi dan perpustakaan di sebuah perusahaan. Bagaimana profesional informasi meyakinkan perusahaan bahwa unit mereka menyediakan informasi yang bernilai bagi bisnis mereka. Menurut Skyrme (2007) Menganalisa informasi apa yang memiliki peran strategis.

Proses ini mencakup analisis kebutuhan informasi perusahaan dan seberapa besar biaya yang mereka sediakan untuk itu. Beberapa keputusan penting yang biasanya ditetapkan oleh perusahaan adalah mengenai :

- pemilihan pasar dan target pasar

- investasi baru

- lokasi pabrik dan kantor

- produk-produk baru yang akan dikembangkan dan yang akan dipasarkan

- Harga dan promosi

Perpustakaan perlu mengetahui bagaimana keputusan-keputusan itu diambil, dan informasi apa saja yang dibutuhkan perusahaan dalam pengambilan keputusan tersebut.

1. Identifikasi kebutuhan pengguna 
Hal ini dapat dilakukan dengan survei, wawancara, dan analisa pemanfaatan. Perpustakaan / unit informasi perlu mencari tahu bagaimana mereka menggunakan informasi yang selama ini disediakan dan hasil serta manfaat apa yang mereka dapat dari informasi tersebut.

3. Tetapkan segmen pengguna

Perpustakaan / unit informasi perlu mengelompokkan pengguna berdasarkan kebutuhan informasi mereka.

4. Ciptakan produk unik

Produk informasi yang dihasilkan, harus diupayakan tersaji dalam bentuk yang lebih menarik sehingga memberikan nilai tambah. Selain itu juga, nilai tambah yang bisa diberikan adalah dengan memberikan informasi lebih dari yang diminta (beyond expectation), namun tentu saja tetap g sesuai dengan kebutuhan mereka.

5. Jual dan pasarkan produk

Perpustakaan dan unit informasi perlu melakukan promosi tentang layanan informasi yang disediakan. Perpustakaan / unit informasi perlu menghadiri pertemuan-pertemuan yang dilakukan perusahaan untuk melakukan promosi

6. Evaluasi dan feedback

Evaluasi dan feedback perlu dilakukan untuk mengetahui seberapa efektif informasi yang disediakan perpustakaan / unit informasi bagi perusahaan, sehingga dapat dilakukan pengembangan-pengembangan.

7. Manfaatkan ICT

Penggunaan ICT dalam memberikan layanan dan menghasilkan produk informasi adalah hal yang penting dalam menambah nilai informasi yang disediakan oleh perpustakaan / unit informasi

8. Membangun hubungan

Perpustakaan / unit informasi perlu membangun hubungan baik dengan penggunanya.

9. Kembangkan beraneka ragam keterampilan

Pustakawan / profesional informasi perlu terus mengembangkan kemampuan dan kompetensinya agar terus dapat memberikan produk- 
produk informasi dana yang lebih baik lagi bagi perusahaan. Beberapa hal yang perlu dikembangkan adalah :

- pengetahuan mengenai industri yang berkaitan dengan bisnis yang dijalani perusahaan

- tanggap terhadap isu-isu dan tekanan bisnis

- communication skills

- inter-personal skills

- dll

Skryme dan Syamsuddin dalam tulisan mereka juga memberikan beberapa aspek yang dapat menambah nilai pada informasi, yaitu :

- $\quad$ ketersediaan (availability)

- $\quad$ mutakhir (currency)

- $\quad$ relevan (relevancy)

- $\quad$ kemudahan akses, ketepatan perolehan (Accessibility)

- $\quad$ tepat guna untuk berbagai kebutuhan (utility)

- $\quad$ akurat (accuracy)

- $\quad$ valid (validity)

- $\quad$ keandalan (reliability)

- $\quad$ tersaji dengan baik (repackaging)

- $\quad$ dapat digunakan dengan beragam cara (flexibility)

Dengan melihat kompleksitas kreatifitas pustakawan di perpustakaan atau pengelola informasi di dunia informasi tanpa batas ruang dan waktu, maka prospek pusat informasi dan perpustakaan sangat menjanjikan karena dibutuhkan oleh masyarakat pengguna. Pada suatu ketika pusat informasi dan perpustakaan adalah lembaga yang menentukan aktivitas kehidupan manusia. Pusat Informasi dan Perpustakaan menciptakan kemajuan berbudaya, mengembangkan ilmu pengetahuan dan menciptakan peradaban yang tinggi.

\section{KESIMPULAN}

Dengan melihat kompleksitas kreatifitas pustakawan di perpustakaan atau pengelola informasi di dunia informasi tanpa batas ruang dan waktu, maka prospek pusat informasi dan perpustakaan sangat menjanjikan karena dibutuhkan oleh masyarakat pengguna. Pada suatu ketika pusat informasi dan 
perpustakaan adalah lembaga yang menentukan aktivitas kehidupan manusia. Pusat Informasi dan Perpustakaan menciptakan kemajuan berbudaya, mengembangkan ilmu pengetahuan dan menciptakan peradaban yang tinggi.

\section{DAFTAR RUJUKAN}

Bakir. (2007, Nopember 2). Antisipasi era sumber daya informasi. Retrieved from www.bappenas.go.id.

Dick, A. L. (2002). The Philosopy, politics and economics of information. Pretoria: University of South Africa.

Hariyadi, U. (2007). Information repackaging and information consolidation : a brief review. Depok: Workshop Informasi dan Perpustakaan.

Hartono. (2007, Desember 1). Perpustakaan dalam praktek knowledge enabler : perspektif pustakawan. Retrieved from http://jibis.pnri.go.id/files/PERBERDAYAAN\%20PENGETAHUAN $\% 20($ HARTONO)

Hawkins, D. (2001). Information science abstracts : tracking the literature of information science. Journal of the American society for information science, 44-53.

Henczel. (2007, Desember 10). The information audit as a first step towards effective knowledge management. . Retrieved from http://www.ifla.org/VII/d2/inspel/00-3hesu.pdf.

Pendit, P. L. (2003). Penelitian ilmu perpustakaan dan informasi. Jakarta: JIP-FSUI.

Saracevic. (1999). Information science. Journal of the American society for information science, 1051-1063.

Skryme, D. J. (2007, Desember 11). Ten ways to add value to your business. . Retrieved from http://www.skyrme.com/pubs/tenways.htm

Sulistyo-Basuki. (2003). Manajemen arsip dinamis. Jakarta: Gramedia Pustaka Utama.

Suriasumantri. (1993). Filsafat ilmu : sebuah pengantar populer. Jakarta: Sinar Harapan.

Syamsudin. (2007, Desember 10). Kemas ulang informasi. Retrieved from http://bapustarda-

kalsel.go.id/index2.php?option=com_content\&do_pdf=1\&id=33. 
Utoyo, I. M. (2007, Nopember 18). Upaya mengukur kontribusi ICT. Retrieved from http://www.ebizzasia.com/03262005/column,indra,0326.html.

wardiana. (2007, Oktober $30)$. http://www.informatika.lipi.go.id/profil/sejarah-p2i. Retrieved from www.informatika.lipi.go.id.

Warsita, B. (2007). Peranan teknologi informasi dan komunikasi dalam penyelenggaraan pendid9ikan jarak jauh. Journal Teknodik, 22-40.

warsita, B. (n.d.). Peranan teknologi informasi dan komunikasi dalam menyelenggarakan pendidikan jarak jauh. Journal teknodik, 22-40.

White, H., \& McCain, K. (1998). Visualizing a displine : an author cocitation analysis of information science. Journal of the American society for information science, 327-355. 